\title{
The Influence of Celebrity Endorsement Types and Congruency Celebrity with the Body Care Products on Instagram Users' Intention to Purchase
}

\author{
Ratu Laila ${ }^{1}$, Bertina Sjabadhyni ${ }^{2}$ \\ ${ }^{1,2}$ Psychology, University of Indonesia, Depok, Indonesia \\ *E-mail: ratulaila96@gmail.com
}

\begin{abstract}
This study aimed to examined the influence of types of celebrity endorsement and congruency celebrity with the product on purchase intention on Instagram users. This study were experimental online research with $2 \times 2$ factorial ANOVA between-subject design. Celebrity endorsement types (famous celebrity vs non famous celebrity) was varied, along with congruence between celebrity and product (higher vs lower congruency). Participants were 774 people aged 18-25 years who classified as the most Instagram users. Results showed that purchase intention score on famous celebrity was significantly higher than non famous celebrity. Meanwhile, congruency between celebrity and product did not significantly affect purchase intention. Therefore, it could be concluded that the type of celebrity endorsement affect purchase intention, while congruency between celebrity and product did not affect purchase intention. The implications of this research can be useful to help marketers choose the right type of celebrity endorsement in creating ads.
\end{abstract}

Keywords: celebrity endorsement type; congruency celebrity with the product; instagram; online experiment; purchase intention

\section{Introduction}

Global competition in the 21 st century is becoming more intense, global competitors make efforts to increase sales in new markets, online, create personal brands, as well as in stores (Eboreime \& Adedoyin, 2013). Indonesia is one of the developing countries in Asia that also competes in global competition. According to Ziraga and Wandebori (2015) Indonesia has a target to increase industrial growth for the next 5 years. Increased growth of the industry, causing the company to find a more innovative way to promote goods and services (Nyarko, Tsetse, \& Avorgah, 2015). In promoting it, companies usually use celebrity endorsement. McCracken (1989) defines celebrity endorsement as all individuals who are known or respected by society and take advantage of their fame to be good consumer in an advertisement. Companies willing to spend a lot of money to use celebrity endorsements. Celebrities have an attractive appearance can affect consumers with its appeal, which will ultimately lead to consumer confidence and the desire to buy products (Khan, Rukhsar, \& Shoaib, 2016).
Celebrity endorsement can be an important thing, because every day consumers get about 1,500 ad exposure from various sources (Ndlela \& Chuhu, 2016).

Comparing celebrity endorsement types, between famous celebrities and non famous celebritites, famous celebrities are usually more preferable. According to Ahmed, Seedani, Ahuja, and Paryani (2015) consumers are more interested in seeing ads that use famous celebrities, because it is considered more interesting and fun. Famous celebrities have a positive impact on consumer perceptions because they are perceived as having credibility in conveying the message and many people adore it. However, sometimes famous celebrities can also impair the brand image if there is negative news about them (Saaed, Naseer, Haider, \& Naz, 2014). Therefore, some other marketers prefer to use non famous celebrities to promote their products. The decision of the marketer to choose the celebrities for the ad is not only seen from celebrity endorsement types, but also must pay attention to the congruency between celebrity with the product. According to 
Kamnis (1990) consumers not only pay attention to the of celebrity endorsement in advertising, but also the characteristics of products that are congruent with celebrities. This is called the match up hypothesis.

According to Kahle and Homer (1985) match-up hypothesis or congruency between celebrity with the product is a message conveyed by celebrities and the message of the product must be congruent for the advertisement to be effective. According to Kamnis and Gupta (1994) there are two factors that influence the match-up hypothesis or the congruence of celebrities with the product, namely the factor of internalization and identification in social influence theory. In internalization, someone imitates the attitude or behavior of celebrity endorsement because the behavior is considered honest and sincere. While the identification arises when a person imitates the behavior or opinion received from others because someone assesses the behavior of others is equal to himself.

The reference study used is a study by McCormick (2016) about the influence of a product-endorser (famous vs. non famous) match on millennials attitudes and purchase intentions. This study shows that congruency between famous celebrities and products can affect purchase intentions, but does not affect their positive attitudes toward advertisement and brand. Another study that inspires this study is a study conducted by Kamnis and Gupta (1994). The study was a $2 \times 2$ experimental study that examined the effect of congruency between the endorsement types (celebrity vs. non-celebrity) with the product toward trust and interest in endorsement types. The results showed that high congruency between endorsement types and product leads to greater trust toward endorser. Furthermore, although celebrity and non celebrity have a high congruency with the product, only celebrity were significantly more appealing.

Both reference studies showed that congruency celebrity with the product can affect purchase intention. In addition, famous celebrity are judged to be more influential toward purchase intention than with non famous celebrity. Therefore, we interested to make experiment study with $2 \times 2$ factorial between subjects design to test the celebrity endorsement types (famous celebrity vs. non famous celebrity) and congruency celebrity with the product (high congruency vs. low congruency).
The objective of this study is to examine whether the purchase intention based on famous celebrity is higher than non famous celebrity on Instagram, whether the purchase intention based on high congruency celebrity with the product is higher compared to low congruency celebrity with the product on Instagram, and if there any signficant interaction between celebrity edorsement types and congruency celebrity with the product. This research is a novel study in Indonesia, since previous research was conducted in America (McCormick, 2016, Kamnis \& Gupta, 1994) and Tunisia (Gaied, 2010).

This study used female participants who classified as the most aged category for Instagram users. This study use Instagram media, because based on observations, many ads on Instagram that use celebrity endorsement. In addition, since 2012, Instagram has grown into one of the most popular social media applications in the world (Fajrina, 2016). Based on our observation, advertisement which often presented in Instagram is advertisement of body care product. Therefore, advertising of body care products, such as shampoo, bath soap, facial soap, body lotion, etc. were used in this study. We will use fictitious advertisements to obtain accurate data.

This study will focus on testing the influence of celebrity endorsement types (famous vs non famous) and the congruency between celebrity and product (high congruency vs. low congruency) on purchase intentions.

\section{Purchase Intention}

According to Lin and Lu (2010) purchase intention is the intention consumer to buying a product that formed by their evaluation or attitude towards a particular product. According to Shao et al., (2004) purchase intention is attempt to buy or visit a store that provides products or services.

\section{Hypothesis}

Ha 1: Purchase intention on famous celebrity endorsement group was higher than non famous celebrity group

Ha 2: Purchase intention on high congruency celebrity with the product group was higher than low congruency celebrity with the product group Ha 3: There was a significant interaction between the type of celebrity endorsement and congruency celebrity with the product on purchase intention 


\section{Methods}

Sample. Participants of this study were 774 women Instagram user aged range from 18 to 25 years old.

Research Design. This study is an experimental research with $2 \times 2$ factorial ANOVA betweensubject design. There are four experimental groups, which were group that get famous celebrity and high congruency with product, group that get famous celebrity and low congruency with product, group that get non famous celebrity and high congruency with the product, and group that get non famous celebrity and low congruency with the product.

\section{Instrument and Measurement}

\section{Pilot Study}

We conducted pilot study to get two name of famous celebrity and non famous celebrity. We used a similar method to previously research by Kamnis and Gupta (1994). First, we gave 20 celebrity names (10 famous celebrities and 10 non famous celebritites) to 33 participans who represented sample. We got 10 famous celebrity names from the list of celebrities who have the most followers on Instagram (Wardoyo, 2016), while 10 names of non famous celebrities were obtained from the list of new arrivals celebries (Dzargon, 2016). After giving the list, participant were asked to rate celebrity familiarity levels using the question, "How familiar are you with the celebrities who appear in the ads?". Then, participant was asked to rate from 1 ("Very unfamiliar") to 7 ("very familiar"). Celebrities who had an average score less than 6 will classified as non famous category and more than 6 will classified as famous category. From this pilot study, we got two celebrity names, namely Raisa Andriana who is famous celebrity and has the highest average $(M=6.59)$ and Putri Lana who is non famous celebrity and has lowest average $(M=1.53)$. The selection of these two celebrity names in this study also considered as control technique. In this study, the two celebrities never become an endorser of body care products on Instagram.

\section{Manipulation of Celebrity Endorsement}

At the time of the study, participants were randomly assigned to one of the treatment groups, which were famous celebrity with high congruency, famous celebrity with low congruency, non famous celebrity with high congruency, and non famous with low congruency. Manipulation was provided by asking participants to imagine if they are exploring Instagram and find the ad upload. Furthermore, they were asked to rate the celebrity familiarity level, using question "How familiar are you to the celebrity featured in the ad?". The participant was then asked to respond to the answer from range 1 ("very unfamiliar") to 7 ("very familiar").

\section{Congruency Celebrity with the Product Instrument}

Measurement of congruency celebrity with the product using a match-up scale that is an adaptation of the Misra (1986) study. Participants were required to provide an overall assessment of the congrueny of celebrity with the product displayed on ad. There were seven items with 7-point Likert scale $(1=$ strongly disagree, $2=$ disagree, $3=$ somewhat disagree, $4=$ neutral, $5=$ somewhat agree, $6=$ agree, $7=$ strongly agree). We tested the reability of this instrument and obtained the alpha .86 .

\section{Purchase Intention Instrument}

Measurement of purchase intention were adapted from the McCormick research (2016). Participants were asked about their willingness to purchase the products displayed on Instagram uploads. The instrument consists of three items with 5-point Likert scale $(1=$ very unlikely, $2=$ unlikely, $3=$ neutral, $4=$ probable, $5=$ very likely). We tested the reability of this instrument and obtained the aplha .891 .

Procedure. This research was conducted online through a survey platform provided by the University of Indonesia (http://www.survey.ui.ac.id/). After the we compiled the survey page, the questionnaire link was disseminated. If participants were willing to participate, they will open the questionnaire link. The questionnaire link consisted of several stages. The first stage contained self-introductions and participants were asked to complete answers to all questions. The second was the page of the participants' consent. In the third stage, there were instructions and upload images of Instagram ads. In this section, participants were asked to observe the advertisement carefully. Then, the participants filled out the manipulation check regarding the celebrity familiarity level in the advertisement and fill the purchase intention questionnaire. In the next stage, participants were given manipulation check that asked them the congruency celebrity with the 
product. The next stage contained the participants' demographic data, and finally debriefing of the research.

\section{Results}

From the results of experimental data through the online questionnaire, we get participants with a total of 800. Of the total participants, there are 26 participants who did not pass the awareness check so it is not used in data processing. Therefore, the total data used were 774 participants which had the sample propotion among the four treatment groups. All participant were female in the age of range 1825 (23,3\% percent were 18 years old), majority from Jakarta (41,9\% percent), and $93.2 \%$ were college students.

We did manipulation check to make sure all participants identify the celebrity endorsement type and congruency celebrity with the product appropriately. In identifying the type of celebrity endorsement, the results showed that participants significantly assessed Raisa Andriana $(M=6.10$, $\mathrm{SD}=2.55 ; \mathrm{t}(772)=-6397, \mathrm{p}<0.01)$ more familiar than Putri Lana $(\mathrm{M}=5.03, \mathrm{SD}=5.03)$. In the manipulation check of congruency celebrtiy with the product, Raisa Andriana was assessed significantly more congruent with lulur product (M $=29.60, \mathrm{SD}=7.56 ; \mathrm{t}(361)=5.419, \mathrm{p}<0.01)$ compared with deodorant $(\mathrm{M}=25,40, \mathrm{SD}=7,15)$. In addition, Putri Lana was also assessed significantly more congruent with lulur product (M $=26.87, \mathrm{SD}=6.89 ; \mathrm{t}(409)=5.417, \mathrm{p}<0.01)$ compared with deodorant $(\mathrm{M}=23.37, \mathrm{SD}=6.20)$.

Table 1.

Purchase Intention on Four Experimental Group

\begin{tabular}{lccc}
\hline \multicolumn{1}{c}{ Group } & $\boldsymbol{M}$ & $\boldsymbol{S D}$ & $\boldsymbol{N}$ \\
\hline $\begin{array}{l}\text { Famous } \\
\text { Celebrity-High } \\
\text { Congruency }\end{array}$ & 6.07 & 2.65 & 192 \\
$\begin{array}{l}\text { Famous } \\
\text { Celebrity-Low }\end{array}$ & 5.94 & 2.45 & 199 \\
$\begin{array}{l}\text { Congruency } \\
\text { Non Famous } \\
\text { Celebrity-High } \\
\begin{array}{l}\text { Congruency } \\
\text { Non Famous } \\
\text { Celebrity-Low }\end{array}\end{array}$ & 5.17 & 2.21 & 171 \\
Congruency & 4.88 & 1.92 & \\
\hline
\end{tabular}

Table 1 showed that the highest average purchase intention scores were obtained from groups that get famous celebrity and high congruency. In this group, the average purchase intention was 6.07 (SD $=2.655$ ), whereas in the famous celebrity with low congruency group the average score was $5.94(\mathrm{SD}=$ 2.457), while the non famous celebrity with high congruency group had an average 5.17 (SD = 2,210), and non famous celebrity with low congruency group has an average value of 4.88 (SD $=1,921)$.

Table 2.

Two-Way ANOVA Result

\begin{tabular}{|c|c|c|c|c|}
\hline Source & $d f$ & $S S$ & $M S$ & $F$ \\
\hline $\begin{array}{l}\text { Celebrity } \\
\text { Endorsement }\end{array}$ & 1 & 184.69 & 184.79 & 34.28 \\
\hline $\begin{array}{l}\text { Congruency } \\
\text { Celebrity with } \\
\text { the Product }\end{array}$ & 1 & 8.49 & 8.49 & 1.58 \\
\hline $\begin{array}{l}\text { Celebrity } \\
\text { Endorsement } \\
\text { and Congruency } \\
\text { Celebrity with } \\
\text { the Product }\end{array}$ & 1 & 1.29 & 1.29 & .24 \\
\hline Total & 774 & & & \\
\hline
\end{tabular}

Analysis with a two-factor ANOVA showed that there was significant differences in average scores of purchase intention between famous celebrity and non famous celebrity $[\mathrm{F}(1,770)=34.28, \mathrm{p}<.05]$. Furthermore, congruency celebrity with the product did not significantly affect purchase intention [F $(1,770)=1.57, \mathrm{p}>.05]$. There was also non significant interaction effect between the type of celebrity endorsement and congruency celebrity with the product on purchase intention $[\mathrm{F}(1.770)=$ $.24, p>.05]$. From the results, we found that $\mathrm{H} 1$ was supported, but $\mathrm{H} 2$ and $\mathrm{H} 3$ were not supported.

\section{Discussion \& Conclusion}

Discussion. The results of this study indicated that the type of celebrity endorsement affects purchase intentions on ads on Instagram. On hypothesis one, we found that there was a significant difference in the purchase intention average score on ads between famous celebrity and non famous celebrity. Average purchase intentions on ads with famous celebrity were higher than with non famous celebrity. This results was in line with findings that famous celebrities have a greater impact on advertising than non famous celebrities (Saeed et al., 2014; Erdogan, 1999). The different purchase intention may be related to consumer perceptions of famous and non 
famous celebrities. Ads with famous celebrity have a positive impact on consumer perceptions as they have a higher credibility in conveying a message, whereas non famous celebrities are perceived as having lower credibility and no appealing attraction (Saeed et al., 2014). There were several reasons why famous celebrities were more influential to purchase intentions than non-famous celebrities. Famous celebrities were observed to be more eye-catching and fun.

Furthermore, in the hypothesis two, congruency celebrity with the product did not significantly affect purchase intention. This results was inconsistent with findings from previous studies (Kamnis \& Gupta, 1994; McCormick, 2016; Till \& Busler, 2000) who found that high congruency celebrity with products will influence the impact of advertising and increase purchase intentions than low congruency celebrity with product. The difference of findings in this study was predicted because of the effect of familiarity with the celebrities who appear in the ad. In addition, we also suspect the physical attractiveness of each of the different celebrities. Furthermore, differences in findings were also predicted because we only use online surveys. Previous research using offline surveys showed that congruency celebrity with products affects purchase intentions (Kamnis \& Gupta, 1994; McCormick, 2016).

There was also no interaction effect between the type of celebrity endorsement and congruency celebrity with the product on hypothesis three. This result is consistent with previous research conducted by Kamnis and Gupta (1994) stating that there is no significant interaction between celebrity endorsement and congruency celebrity with product in affect purchase intentions. We suspect this result is because in this study participants only focused on one of the independent variables studied. So when participants get ads with famous celebrity endorsements, they only pay attention to their celebrities regardless of the product. When participants get ads with high congruency celebrity with product, he only pay attention to the product alone regardless of the type of celebrity endorsement in advertising.

Based on the results of this study, there were several things that need to be considered for further research. There were some suggestions that can be used to improve future research. First, this study uses only female samples. Therefore, the next research should examine the effect of celebrity endorsement by using women and men. Second, regarding the level of congruency less effective products in influencing purchase intentions, we suggest that further study should compare between celebrity congruency and attraction. Previous research has found that the attraction of celebrities is an important factor that can affect buying intentions (Baker \& Churchill, 1977; Desarbo \& Harshman, 1985; Tinghci, et al., 2007). Third, related to product category used in this research is body care product, next research should use other product category, like sport product. According to Martin (1996), it is important to examine the match up hypothesis in sports products, because if there is little congruency between celebrity and product image, then consumers will give a negative assessment to a endorsement. Fourth, this research only uses Instagram social media platform. Therefore, we recommend further research using other social media platforms that also affect purchase intention, such as Youtube, Line, Snapchat, and so on. Finally, knowing that famous celebrity endorsements can affect purchase intentions, then marketers can request the help of famous celebrities to market their products. The use of famous celebrity endorsements can help promote the product and increase sales because popular celebrity endorsements will be more noticed, remembered, and considered to have higher credibility so that consumers are interested to purchase.

\section{Conclusions}

Overall, the result showed that the average score of purchase intention on famous celebrity is significantly higher than the purchase intention score on non famous celebrity. The result also showed that congruency celebrity with the product did not affect purchase intention. Finally, there is no interaction between the type of celebrity endorsement and congruency celebrtiy with the product.

\section{References}

Ahmed, R. R., Seedani, S. K., Ahuja, M. K., \& Paryani, S. K. (2015). Impact of Celebrity Endorsement on Consumer Buying Behavior. Journal of Marketing Research. 10(1).

Baker, M.J. and Churchill, G.A. (1977). The Impact of Physically Attractive Models on Advertisement Evaluations. Journal of Marketing Research, 14, 538-55

DeSarbo, W.S. \& Harshman, R.A. (1985). CelebrityBrand Congruence Analysis. Journal of Research in Advertising, 1, 17-52

Djafarova, E., \& Rushworth, C. (2017). Exploring the Credibility of Online Celebrities' Instagram Profiles 
in Influencing the Purchase Decisions of Young Female Users. Computers in Human Behavior, 68, $1-7$.

Eboreime, O. F., \& Adedoyin, S. A. (2013). Strategies for Making Competition Irrelevant in the Global Market for Developing Economies. Journal of Emerging Trends in Economics and Management Sciences, 4(3), 297.

Erdogan, B. Z. (1999). Celebrity Endorsement: A Literature Review. Journal of marketing management, 15(4), 291-314.

Fajrina, N. (2016). Ada 22 Juta Pengguna Aktif Instagram dari Indonesia. Diakses pada 11 Juni 2017, dari http://www.cnnindonesia.com/teknologi/201606231 12758-185-140353/ada-22-juta-pengguna-aktifInstagram-dari-indonesia/

Gaied, A. M., \& Rached, K. S. B. (2010). The Persuasive Effectiveness of Famous and Non Famous Endorsers in Advertising. IBIMA Business Review, 1-14. doi: $10.5171 / 2010.474771$

Kahle, L. R., \& Homer, P. M. (1985). Physical Attractiveness of Celebrity Endorser: A Social Adaption Perspective. Journal of Consumer Research, 954-961.

Kamins, M. A., \& Gupta, K. (1994). Congruence Between Spokesperson and Product Type: A Matchup Hypothesis Perspective. Psychology \& Marketing, 11(6), 569-586.

Kamins, M. A. (1990). An Investigation Into the "Match-Up" Hypothesis in Celebrity Advertising: When Beauty May Be Only Skin Deep. Journal of advertising, 19(1), 413.

Karimova, G. Z. (2012). Bakhtin and Interactivity: A Conceptual Investigation of Advertising Communication. USA, Palo Alto: Academica Press, $L L C$.

Khan, K. S., Rukhsar, A., \& Shoaib, M. (2016). Influence of Celebrity Endorsement on Consumer Purchase Intention. Journal of Business and Management, 18(1), 6-9.

Kumar, D. P., \& Raju, K. V. (2013). The Role of Advertising in Consumer Decision Making. IOSR Journal of Business and Management, 14(4), 37-45.

Lin, L. Y., \& Lu, C. Y. (2010). The Influence of Corporate Image, Relationship Marketing, and Trust on Purchase Intention: The Moderating Effects of Word-of-Mouth. Tourism Review, 65(3), 16-34.

Martin, J. H. (1996). Is the athlete's sport important when picking an athlete to endorse a nonsport product? Journal of Consumer Marketing, 13(6), 28-43.

McCormick, K. (2016). Celebrity endorsements: Influence of a product-endorser match on
Millennials attitudes and purchase intentions. Journal of Retailing and Consumer Services, 32, $39-45$.

McCracken, G. (1989). Who is the Celebrity Endorser? Cultural Foundations of the Endorsement Process. Journal of Consumer Research, 16, 310-321.

Nyarko, I. K., Tsetse, E. K., \& Avorgah, S. K. M. (2015). Is Billboard Advertising an Effective Tool in The Marketing of Home Appliances. Asian Journal of Social Sciences and Management Studies, 2(3), 101108.

Ndlela, T., \& Chuchu, T. (2016). Celebrity Endorsement Advertising: Brand Awareness, Brand Recall, Brand Loyalty as Antecedence of South African Young Consumers' Purchase Behaviour. Journal of Economics and Behavioral Studies, 8(2), 79-90.

Saeed, R., Naseer, R., Haider, S., \& Naz, U. (2014). Impact of celebrity and non-celebrity advertisement on consumer perception. The Business \& Management Review, 4(3), 154

Shao, C.Y., Baker, J. and Wagner, J.A. (2004). The Effects of Appropriateness of Services Contact Personnel Dress on Customer Expectations of Involvement and Gender. Journal of Business Research, 57, 1164-76.

Shobika, A. \& Sindhu, J. (2014). A Study on Effective Advertising Management Strategy. International Journal of Research and Development, 72-77.

Terkan, R. (2014). Importance of Creative Advertising and Marketing According to University Students' Perspective. International Review of Management and Marketing, 4(3), 239.

Till, B. D., \& Busler, M. (2000). The match-up hypothesis: Physical attractiveness, expertise, and the role of fit on brand attitude, purchase intent and brand beliefs. Journal of advertising, 29(3), 1-13.

Tingchi Liu, M., \& Brock, J. L. (2011). Selecting a female athlete endorser in China: The effect of attractiveness, match-up, and consumer gender difference. European Journal of Marketing, 45(7/8), 1214-1235.

Ziraga, E. T., \& Wandebori, H. (2015). Strategic Assessment of Indonesian Furniture Industry. Journal of Business and Management, 4(6), 644662. 


\section{Appendix A. Each experiment group stimulus}

Picture 1.

Famous Celebrity-High Congruency

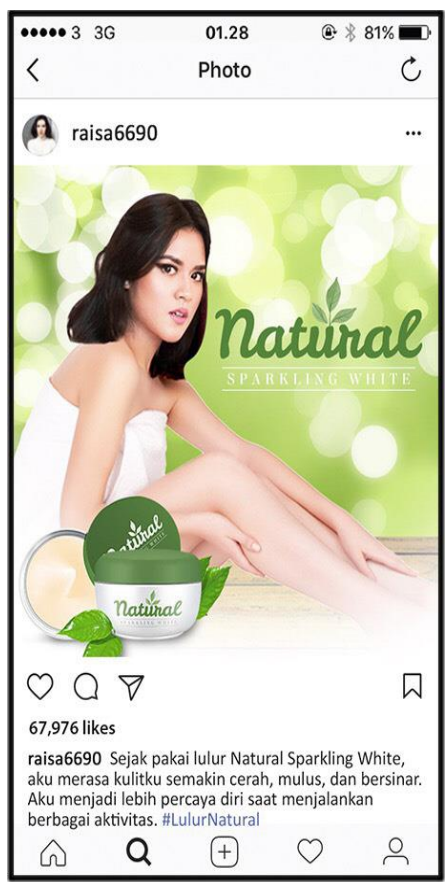

Picture 2.

Famous Celebrity-Low Congruency

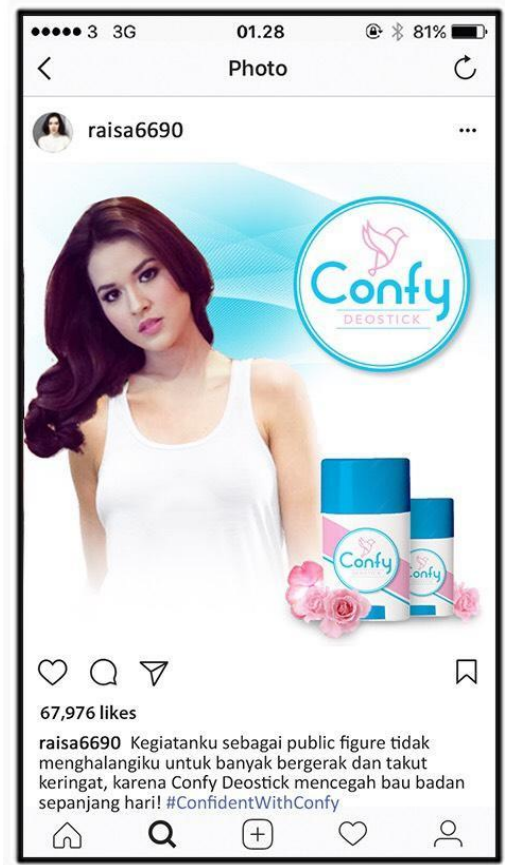

Picture 3.

Non Famous Celebrity-High Congruency

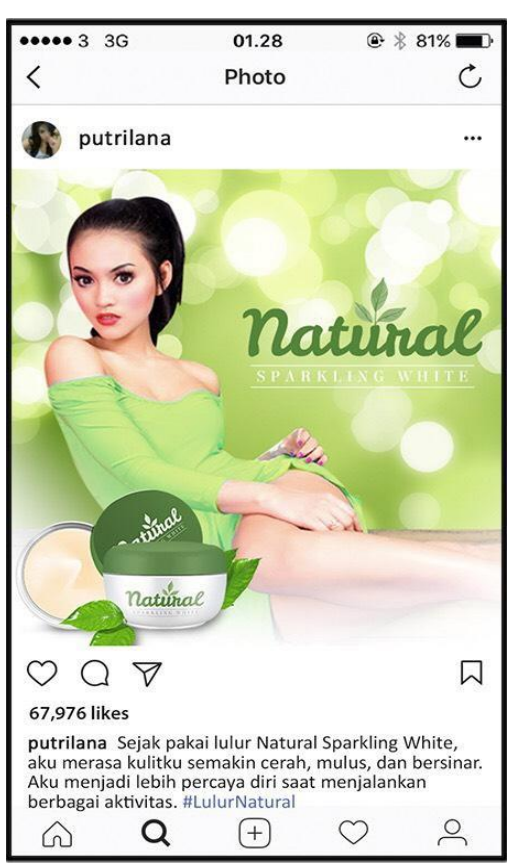

Picture 4.

Non Famous Celebrity-Low Congruency

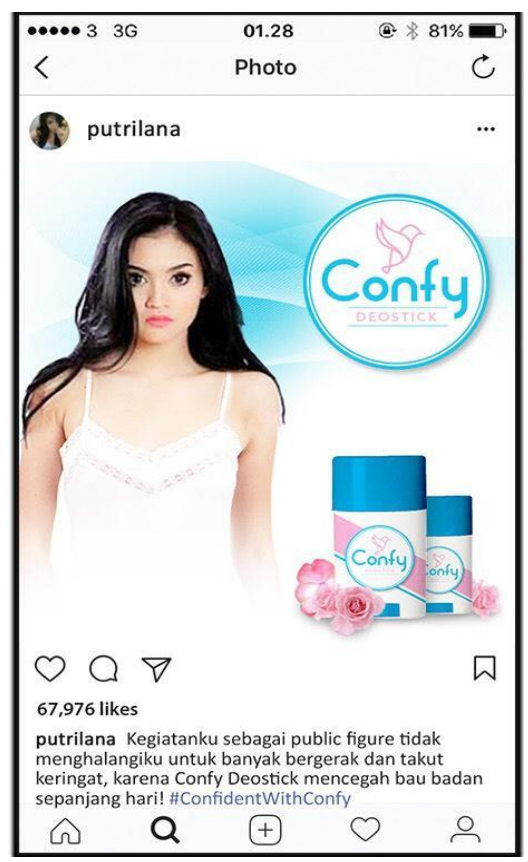

